\title{
E-COMMERCE UNTUK OPTIMALISASI PEMASARAN PRODUK DI ERA DIGITAL BAGI USAHA MIKRO KELOMPOK TANI PANGESTU RAKYAT DESA BARUMANIS KABUPATEN REJANG LEBONG
}

\author{
Nanang Sugianto ${ }^{*}$, Ferzha Putra Utama ${ }^{2}$ \\ ${ }^{I}$ Program Studi Geofisika, Jurusan Fisika, Fakultas MIPA, Universitas Bengkulu, Bengkulu, Indonesia \\ ${ }^{2}$ Program Studi Sistem Informasi, Fakultas Teknik, Universitas Bengkulu, Bengkulu, Indonesia \\ * Penulis Korespodensi : nanang.s@unib.ac.id
}

\begin{abstract}
Abstrak
Permasalahan pokok yang dialami oleh Kelompok Tani Pangestu Rakyat Desa Barumanis dalam membangun usaha mikro produksi bubuk kopi mulai dari permasalahan pengemasan hingga pemasaran produk "Pandu Coffee" telah berangsur terselesaikan. Sistem pengemasan dan pemasaran sudah serba bersentuhan dengan teknologi dan menyesuaikan dengan kemajuan era digital. Program pengabdian masyarakat ini dilakukan dengan pendekatan partisipatif yang menerapkan setidaknya empat metode antara lain metode pendidikan, pelatihan, subtitusi dan difusi IPTEKS. Metode pendekatan teori dan praktek meliputi pendampingan pengetahuan TIK untuk meningkatkan kemampuan dalam merancang, mambuat dan menerapkan kemasan produk dan e-commerce sebagai instrumen pemasaran dan penjualan secara online. Hasil yang dicapai bersama mitra antara lain pembaruan wujud kemasan produk kopi dan terciptanya sistem pemasaran produk yang dilakukan secara online seperti media sosial (Gmail, facebook, Instagram, dan youtube) dan website. Produk Pandu Coffee saat ini berangsur semakin dikenal banyak orang yang ditandai dengan bertambahnya jumlah pengunjung yang mengunjungi media sosial dan website Pandu Coffee. Calon pelanggan dapat memesan produk melalui Shoppee dan Tokko.io sebagai marketplacenya. Setelah menerapkan e-commerce, penjualan produk mitra meningkat signifikan, yaitu menjual 500 bungkus $(125 \mathrm{Kg}$ ) dan menghasilkan laba hingga Rp. 5.000.000,- hanya selama 2 bulan. Perbaikan kemasan dan penerapan e-commerce pada produk mitra dinilai efektif untuk menambah pendapatan mitra.
\end{abstract}

Kata kunci: kemasan, e-commerce, Pandu Coffee, Kelompok Tani Pangestu Rakyat, Barumanis

The main problems in coffee business of Pangestu Rakyat (Farmer Group) such as packaging and marketing problems have been gradually resolved. The packaging and marketing system is all in touch with technology and adapts to the digital era. This community service program is carried out with a participatory approach that applies at least four methods: educational, training, substitution, and science and technology diffusion. The theoretical and practical approaches include mentoring ICT knowledge to improve the ability to design, manufacture and implement product packaging and e-commerce as an online marketing and sales instrument. The results of this program is renew the form of packaging and create online marketing systems such as social media (Gmail, Facebook, Instagram, and YouTube) and websites. Pandu Coffee are becoming known to many people as indicated by the increasing visitors to visit social media and the Pandu Coffee website. Prospective customers can order products through Shoppee and Tokko.io as its marketplaces. After implementing e-commerce, sales of products increased significantly, namely selling 500 pcs $(125 \mathrm{Kg})$ and generating profits up to Rp. 5,000,000, - only for 2 months. Packaging improvements and the application of e-commerce to products are considered effective in increasing partner income.

Keywords: packaging, e-commerce, pandu coffee, Pangestu Rakyat farmer group, Barumanis

\section{PENDAHULUAN}

Kelompok Tani Pengestu Rakyat merupakan salah satu kelompok tani yang ada di Desa Barumanis Kecamatan Bermani Ulu Kabupaten Rejang Lebong
Provinsi Bengkulu, Indonesia. Kelompok Tani Pangestu Rakyat beranggotakan 20 orang dengan usia anggota tersebar dari 23-45 tahun. Kegiatan utama kelompok tani ini adalah petani kopi. Kelompok Tani Pangestu Rakyat 
sedang membangun usaha mikro produksi kopi bubuk. Kopi bubuk yang diproduksi oleh Kelompok Tani Pengestu Rakyat memiliki citra rasa yang khas dengan teknik olahan khusus (rahasia keluarga). Usaha mikro produksi kopi bubuk milik Kelompok Tani Pangestu Rakyat dimulai pada bulan Mei tahun 2019 (awal masa panen tahunan). Kualitas kopi bubuk begitu dijaga dengan cara salah satunya adalah hanya memanfaatkan buah kopi petik merah (Gambar 1.a). Biji kopi disangrai dan digiling menjadi kopi bubuk menggunakan mesin roasting (Gambar 1b) berkapasitas $5 \mathrm{~kg}$ dan mesin penggiling milik ketua kelompok tani (Gambar 1.c).
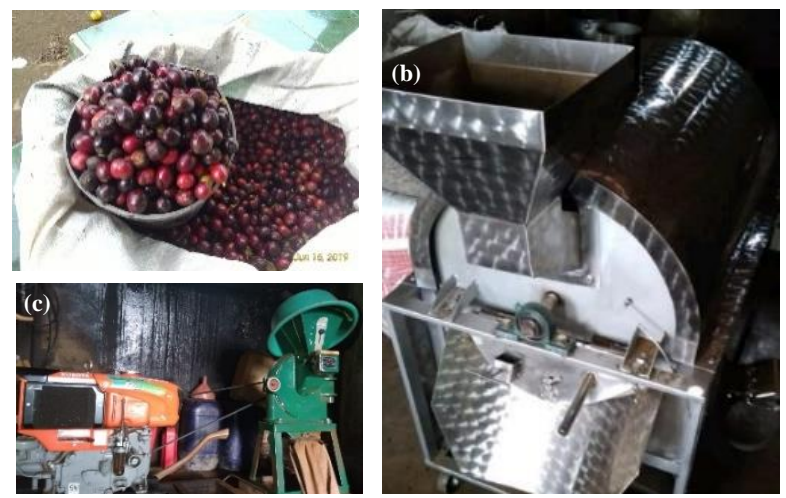

Gambar 1. (a) Buah kopi petik merah, (b) dan (c) mesin roasting dan mesin giling kopi yang dimiliki mitra.

Produk kopi dikemas dengan plastik PP pouch polos (bening) jenis Zipper yang diberi merk "Pandu Kopi" dengan massa 250 gram per kemasan (Gambar 1c) dan harga Rp. 15.000. Identitas produsen dibuat dalam bentuk kertas stiker berukuran kecil yang ditempelkan pada bagian depan kemasan plastik. Keterbatasan peralatan dan keterampilan SDM mitra menjadikan kemasan produk dibuat seadanya.
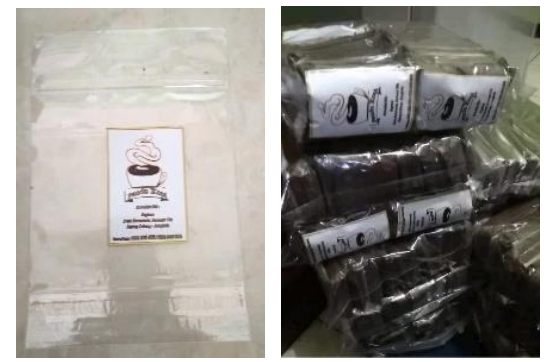

Gambar 2. Kemasan produk kopi bubuk milik mitra yang telah dipasarkan sejak tahun 2019.

Informasi Penjualan kopi bubuk sejak Mei 2019 hingga Maret 2020 disajikan pada Tabel 1. Selama durasi ini, mitra melakukan produksi kopi paling banyak $55 \mathrm{~kg}$ dengan 7 kali proses produksi. Modal produksi mitra terbilang cukup rendah dengan rata-rata Rp. 50.000,- per proses. Ini dikarenakan mitra tidak membeli biji kopi, mengeluarkan dana roasting kopi dan penggilingan kopi bubuk. Produksi $55 \mathrm{~kg}$ kopi bubuk termasuk pengemasan menghabiskan modal Rp. 880.000,- dan menghasilkan 220 bungkus kemasan. Laba yang diperoleh dari penjualan $55 \mathrm{~kg}$ bubuk kopi mencapai Rp. 2.420.000. Besaran laba ini membuktikan bahwa usaha mikro yang dirintis oleh Kelompok Tani Pangestu Rakyat dalam memproduksi kopi bubuk selama bulan Mei 2019 hingga Maret 2020 berpotensi besar menjadi kegiatan positif yang memberikan kesejahteraan ekonomi bagi anggota.

Tabel 1. Informasi produksi hasil penjualan kopi bubuk "Pandu Kopi" milik Kelompok Tani Pangestu Rakyat sejak Mei tahun 2019 sampai dengan Maret 2020

\begin{tabular}{|c|c|c|c|c|c|c|}
\hline No & Bulan & $\begin{array}{c}\text { Produksi } \\
\text { (Kg)/ } \\
\text { (kemasan) }\end{array}$ & $\begin{array}{l}\text { Modal } \\
\text { (Rp) }\end{array}$ & $\begin{array}{c}\text { Terjual } \\
\text { (Kg)/ } \\
\text { (kemasan) }\end{array}$ & $\begin{array}{l}\text { Penjualan } \\
\text { (Rp) }\end{array}$ & $\begin{array}{l}\text { Laba } \\
\text { (Rp) }\end{array}$ \\
\hline 1 & Mei & $\begin{array}{l}15 /(60) \\
\end{array}$ & 240.000 & $\begin{array}{l}10 /(40) \\
\end{array}$ & 600.000 & 150.000 \\
\hline 2 & Juni & $10 /(40)$ & 160.000 & $12 /(48)$ & 720.000 & 260.000 \\
\hline 3 & Juli & $5 /(20)$ & 80.000 & $6 /(24)$ & 360.000 & 130.000 \\
\hline 4 & Agustus & $10 /(40)$ & 160.000 & $11 /(44)$ & 660.000 & 230.000 \\
\hline 5 & September & $5 /(20)$ & 80.000 & $6 /(24)$ & 360.000 & 130.000 \\
\hline 6 & Oktober & $5 /(20)$ & 80.000 & $2 /(8)$ & 120.000 & 10.000 \\
\hline 7 & November & 0 & 0 & 0 & 0 & \\
\hline 8 & Desember & $5 /(20)$ & 80.000 & $6 /(24)$ & 360.000 & 130.000 \\
\hline 9 & $\begin{array}{c}\text { Januari } \\
2020\end{array}$ & 0 & 0 & $1 /(4)$ & 60.000 & 30.000 \\
\hline 10 & $\begin{array}{l}\text { Februari } \\
2020\end{array}$ & 0 & 0 & $1 /(4)$ & 60.000 & 30.000 \\
\hline 11 & $\begin{array}{c}\text { Maret } \\
2020 \\
\end{array}$ & 0 & 0 & 0 & 0 & 0 \\
\hline \multicolumn{2}{|c|}{$\begin{array}{l}\text { Jumlah Total } \\
\text { (Kg/Kemasan) }\end{array}$} & $55 /(220)$ & 880.000 & $55 /(220)$ & 3.300 .000 & 2.420 .000 \\
\hline
\end{tabular}

Dampak dari sistem yang selama ini digunakan oleh mitra, menyebabkan permintaan dari konsumen mulai menurun drastis sejak bulan Januari 2020 (Tabel 1). Pelaku usaha mikro milik Petani Pangestu Rakyat yang merupakan mitra dalam kegiatan pengabdian kepada masyarakat, meminta tim mengadakan pelatihan dan pendampingan untuk optimalkan pemasaran dan penjualan produk kopi bubuk "Pandu Kopi". Mitra menyadari bahwa pemasaran perlu ditingkatkan yang diawali dengan peningkatan kualitas kemasan produk. Selain itu, mitra juga membutuhkan suatu media promosi dan pemasaran produk berbasis teknologi digital marketing (online) atau dikenal dengan e-commerce untuk memperkenalkan kepada masyarakat luas tentang hasil olahan yang berasal dari Desa Barumanis.

E-commerce adalah suatu proses membeli dan menjual produk-produk secara elektronik oleh konsumen dan dari perusahaan dengan komputer sebagai perantara transaksi, yaitu memanfaatkan teknologi berbasis jaringan peralatan digital (Pitriyani dan Kasmi, 2019). Pemanfaatan e-commerce memberikan kemudahan kepada mitra UKM untuk melakukan pemasaran, mengorganisir pesanan konsumen dan melakukan transaksi secara efektif (Rahman dan Ramdani, 2016; Yulistia, 2017). Selain memberikan kemudahan, pemasaran produk mitra melalui e-commerce memiliki nilai informatif, persuasif (meyakinkan), intention (memiliki daya tarik) yang tinggi (Utami dan Aini, 2019), operasi yang lebih cepat dan lebih baik (Nasrullah dkk, 
2017). Penggunaan $e$-commerce dapat membangun faktor trust baik pemasok maupun pelanggan (Disa, 2011). Pemanfaatan teknologi e-commerce juga berperan untuk memenuhi dan peningkatan strategi pemasaran produk (Wibawa dan Fahrizal, 2019) yang dapat berdampak pada pengurangan biaya operasional ((Maulana dkk, 2015) dan peningkatan pendapatan (Mumtahana dkk, 2017). Saat ini, fasilitas e-commerce tidak hanya memberikan kemudahan akses (Irmawati, 2011) penjual dan pembeli di dalam negeri tetapi juga mencakup perdagangan internasional (Sugiyanto dkk, 2017; Wibawa dan Fahrizal, 2019). Hal tersebut karena dengen sistem $e$ commerce, transkasi jual beli dapat dilakukan di manapun, dari manapun, dan kapanpun (Pitriyani dan Kasmi, 2019).

Berdasarkan prinsip e-commerce, Penerapan $e$ commerce diyakini dapat menjadi salah satu solusi terhadap persoalan pemasaran yang dialami oleh mitra. Setidaknya, penerapan e-commerce dapat meningkatkan layanan konsumen dan citra produk menjadi baik, menemukan partner bisnis baru, proses menjadi sederhana dan waktu dapat dipadatkan, dapat meningkatkan produktivitas, akses informasi menjadi cepat, penggunaan kertas dapat diminimalkan, biaya transportasi berkurang dan fleksibilitas bertambah.

\section{METODE}

Berdasarkan hasil identifikasi permasalahan dan Focus Group Discussion (FGD) bersama mitra, solusi yang disepakati untuk menyelesaikan permasalahan mitra yaitu melalui kegiatan pendidikan, pelatihan dan pendampingan dengan metode pendekatan teori dan praktek. Pelaksanaan program ini dilakukan di kediaman ketua Kelompok Tani Pangestu Rakyat (Bapak Sugiono) yaitu di Desa Barumanis Dusun 6. Pelaksanaan kegiatan ini dilakukan selama 3 kali pertemuan dalam 2 bulan yaitu pertemuan pertama kepada seluruh anggota kelompok tani (kegiatan pendidikan dan pelatihan), pertemuan kedua kepada dua anggota kelompok yang ditunjuk sebagai admin operasi media sosial, website dan marketplace serta pertemuan ketiga kepada seluruh anggota kelompok tani kembali dengan kegiatan mensosialisasikan dan launching produk (kemasan dan sistem e-commerce) yang telah dibuat.

Beberapa tahapan yang dilakukan dalam proses pengabdian antara lain tahap pesiapan, pelaksanaan kegiatan serta tahap monitoring dan evaluasi. Tahap persiapan meliputi penyusunan rencana dan jadwal kegiatan, sosialisai jadwal kegiatan, pengumpulan alat dan bahan, pembuatan modul pendidikan, rancangan kemasan terbaru, dan rancangan halaman website untuk e-commerce. Selanjutnya, tahap pelaksanaan kegiatan meliputi pendidikan, pelatihan, praktek dan pendampingan mulai dari pengenalan, standarisasi kemasan produk yang menarik hingga teknik pemasaran yang mengimplementasikan $e$-commerce.

Selain bentuk dan model kemasan, khalayak sasaran juga diberi pengetahuan standar kelengkapan dan keamanan dalam pengemasan produk seperti merk produk, tanggal batas akhir penggunaan produk, label informasi kesehatan produk dri BPOM, kemasan yang dipress menggunakan mesin sealer dan lainnya. Mitra juga dibekali pengetahuan dalam menginisiasi pengurusan izin PIRT dan label halal dari dewan MUI terkait serta dan label informasi kesehatan produk dari BPOM.

Terkait dengan keterbatasan kemampuan dan sumberdaya, sistem e-commerce dikembangkan secara partisipatif dengan pendekatan bottom-up melalui metode transfer pengetahuan. Penerapan pengetahuan secara teori dan praktek tersebut meliputi: (1) pengenalan internet, mesin pencarian dan e-mail, (2) membangun dan operasi website, (3) pengenalan e-commerce termasuk media sosial, (4) instalasi e-commerce, (5) manajemen konten, (6) manajemen persediaan produk, (7) manajemen transaksi, dan (8) manajemen pemasaran. Melalui pendekatan tersebut, mitra diharapkan mampu menjalankan, mengelola, dan menjamin keberlangsungan atas aplikasi $e$-commerce yang sudah dikembangkan dengan terus didampingi oleh tim pengabdian.

\section{HASIL DAN PEMBAHASAN}

Kegiatan pendidikan kepada mitra mulai dilakukan pada 29 Agustus 2020. Kegiatan ini diikuti 25 orang dimana 20 orang adalah anggota kelompok Tani Pangestu Rakyat dan 5 orang lainnya anggota kelompok tani lain yang ada di Desa Barumanis. Kegiatan ini juga dibantu oleh beberapa mahasiswa program studi Fisika dan program studi teknik Sistem Informasi. Tahapan pertama sebelum melakukan kegiatan pendidikan baik sesi kelas maupun sesi lapangan adalah tahapan persiapan. Tahapan persiapan meliputi persiapan peralatan dan pembuatan modul singkat pelatihan untuk khalayak sasaran. Beberapa modul pelatihan diantaranya adalah cara dan standarisasi pembuatan kemasan produk yang materinya disampaikan oleh Nanang Sugianto, S.Si., M.Sc dan materi tentang e-commerce diberikan oleh Ferza Utama Putra, S.T., M.Eng. Selain modul pelatihan, rancangan kemasan terbaru produk kopi milik mitra dan beberapa media e-commerce yang nantinya akan digunakan, juga menjadi bahan dan peralatan yang digunakan dalam proses pendidikan dan pelatihan.

Mitra diberi pengetahuan mengenai komponen dasar dalam perancangan dan pembuatan kemasan produk dan hal yang membedakan sistem pemasaran dan penjualan secara offline dan online. Praktik (pelatihan sesi lapangan) yang terlihat pada Gambar 3 merupakan tahapan kegiatan yang tidak terpisahkan dari serangkaian kegiatan pengabdian kepada masyarakat Kelompok Tani Pangestu Rakyat Desa Baru Manis. Salah satu kegiatan 
pada tahapan ini adalah khalayak sasaran diberitahu dan dilatih menggunakan beberapa peralatan yang berhubungan dengan pengemasan produk seperti alat pemotong kertas, kertas stiker, kemasan standing pouch kraft jendela, dan kemudian kemasan ditutup rapat menggunakan mesin sealer.

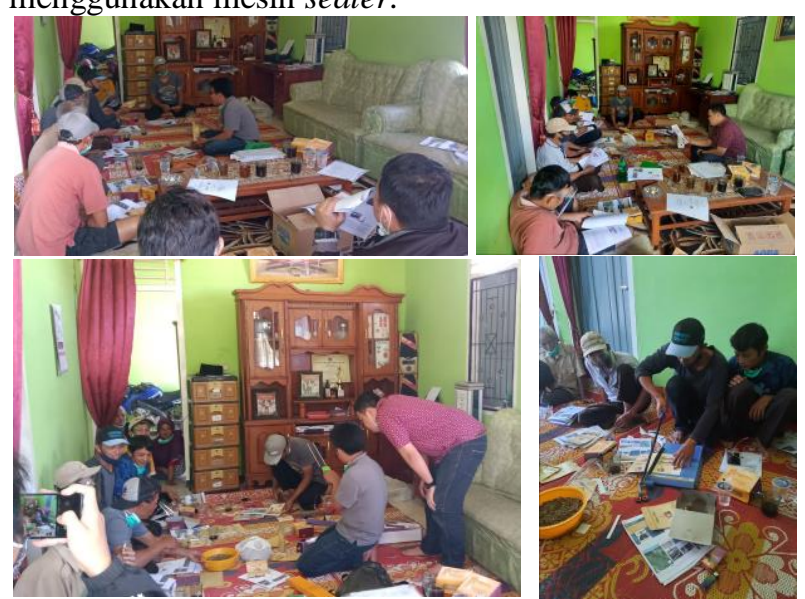

Gambar 3. Kegiatan praktik penyelesaian pembuatan kemasaan produk

Kemasan seringkali disebut sebagai "the silent sales-man/girl" karena mewakili ketidakhadiran pelayan dalam menunjukkan kualitas produk, nilai jual dan keamanan produk (Sugiyanto dkk, 2017). Sebuah kemasan suatu produk harus mampu menyampaikan pesan lewat komunikasi informatif, seperti halnya komunikasi antara penjual dengan pembeli (Zen dkk, 2017). Sebagai alat untuk mempromosikan produk, kemasan harus sesuai dengan fungsi yang akan dibidik oleh para produsen (Harminingtyas, 2013). Produk yang akan dipasarkan secara online harus memiliki tampilan yang menarik, unik dan terlihat meyakinkan. Tim pengabdian bersama mitra telah mendesain brand untuk kemasan produk (Gambar 4a). Wujud kemasan produk lama kini telah bermigrasi kepada wujud kemasan produk terbaru seperti yang terlihat pada Gambar 4b. Produk semula adalah "Pandu Kopi" di upgrade menjadi "Pandu Coffee". Kemasan produk terbaru juga dilengkapi pelaku produksi, alamat produksi, kontak produsen serta media pemasaran online seperti Whatsapp, facebook, Instagram, dan website. Media-media ini berperan memberi informasi kepada pelanggan mengenai ragam, profil dan kegiatan-kegiatan mitra dalam produksi bubuk kopi. Pada kemasan produk juga diberi informasi bahwa program ini didampingi oleh tim PPM penerapan IPTEKS LPPM Universitas Bengkulu untuk keperluan promosi.

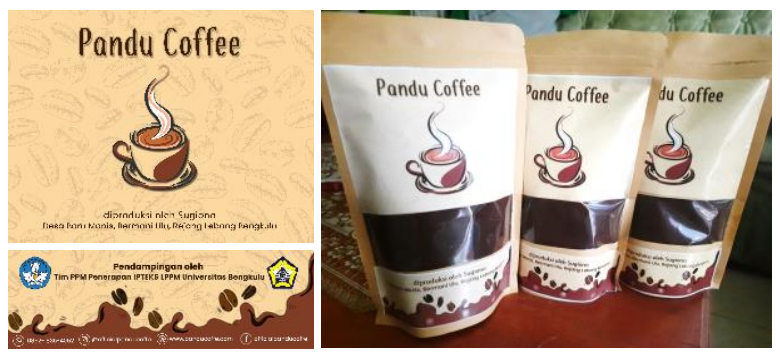

Gambar 4. Kemasan produk kopi terbaru milik mitra yaitu "Pandu Coffee".

Bagi mitra, E-commerce dimanfaatkan sebagai media untuk memperkenalkan, menjelaskan, memasarkan dan menjual produk pandu coffee kepada pecinta kopi di era digital. E-commerce dinilai juga mampu menjadi aplikasi untuk memonitoring jumlah produk yang tersedia atau disebut ready stock (Hadiwijaya dkk, 2019). E-commerce lebih dikenal sebagai toko online (Sutanto dkk, 2015). Beberapa media e-commerce yang telah dibangun bersama kelompok Tani Pangestu Rakyat diantaranya adalah alamat G-mail, youtube, facebook, Instagram dan website. Alamat e-mail atau $G$-mail merupakan akun yang pertama kali harus dimiliki untuk membangun sistem e-commerce. Akun Gmail kemudian digunakan untuk membuat akun youtube, facebook, Instagram, website dan marketplace yang akan digunakan untuk memasarkan produk. Tim pengabdian telah membangun akun youtube "Pandu coffee", dimana akun ini dapat digunakan oleh mitra sebagai media mempublikasikan kegiatan produksi pandu coffee berupa video mulai dari dari tahapan perawatan kopi, profil perkebunan kopi, sistem pengeringan kopi, penggilingan kopi hingga teknik penyeduhan ternikmat untuk produk coffee. Video tesebut juga dipublikasikan pula pada halaman facebook, instagram dan website. Youtube "Pandu coffee" telah mempbulikasikan 1 video yang berisi serangkaian kegiatan bersama mitra pada program pengabdian kepada masyarakat berbasis IPTEKS tahun 2020 LPPM Universitas Bengkulu dengan judul "Apa itu Pandu Coffee?" (Gambar 5).

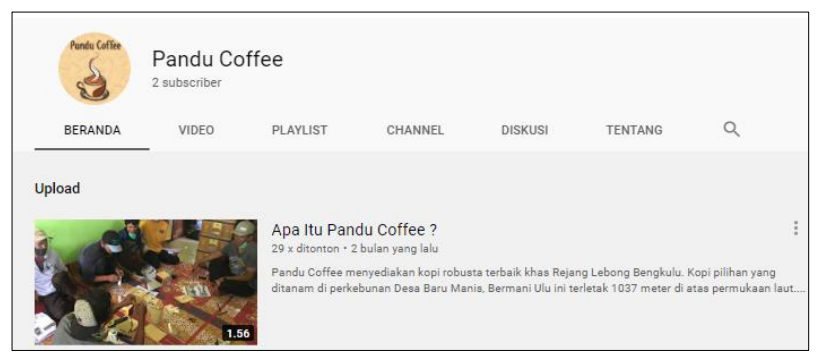

Gambar 5. Hasil Screenshoot youtube Pandu coffee.

Selain youtube, media lain yang digunakan untuk melakukan pemasaran produk pandu coffee adalah facebook. Facebook merupakan media sosial yang ramai 
digunakan untuk melakukan komunikasi hingga melakukan pemasaran dan penjualan produk antara penjual dan pembeli. Tim pengabdian telah membangun akun facebook pandu coffee yang diberi nama "Officialpanducoffee". Fungsi akun facebook ini sama dengan youtube, yaitu untuk melakukan pengenalan dan pemasaran produk yang dimiliki oleh mitra. Terakhir, website juga menjadi media utama lainnya yang digunakan untuk memasarkan produk mitra. Website tersebut diberi nama "Pandu coffee". Banyak hal yang disampaikan dalam website ini, mulai dari profil daerah produksi kopi hingga proses pemesanan yang bisa dilakukan oleh calon pembeli melalui kontak langsung (no telepon gengam) dan melalui marketplace yang telah disiapkan. Salah satu anggota Kelompok Tani Pangestu dirakyat ditugaskan menjadi website admin. Admin diberi pengetahuan, dilatih dan didampingi bagaimana Langkah-langkah dalam melakukan operasi penggunaan dan pengisian website. Admin juga diberi buku panduan operasi website yang nantinya akan memudahkan admin dalam melakukan tugasnya. Adapun daftar kumpulan akun dan link e-commerce produk Pandu Coffee milik usaha bersama Kelompok Tani Pangestu Rakyat terangkum pada Tabel 2. Screenshot halaman website, facebook, instagram, dan marketplace (shopee dan tokko.io) ditunjukkan pada Gambar 6.

Tabel 2. Daftar nama akun, link media sosial, website dan marketplace Pandu Coffee

\begin{tabular}{|c|c|c|}
\hline No & $\begin{array}{l}\text { Nama } \\
\text { Media }\end{array}$ & Akun/alamat \\
\hline 1 & Gmail & Officialpanducoffee@gmail.com \\
\hline 2 & Youtube & $\begin{array}{l}\text { Pandu coffee: } \text { https://www.youtube.com/channel/UCnl8oBIL- } \\
\text { b7qNf72BW9EuWQ }\end{array}$ \\
\hline 3 & Facebook & https://web.facebook.com/officialpanducoffee?_rdc=1\&_rdr \\
\hline 4 & Instagram & https://www.instagram.com/officialpanducoffee/ \\
\hline 5 & Website & $\begin{array}{l}\text { http://www.panducoffe.com } \\
\text { - } \quad \text { Shopee: } \\
\text { https://shopee.co.id/panducoffee?categoryId=157\&itemId= }\end{array}$ \\
\hline 6 & Marketplace & $\begin{array}{l}7960893370 \\
\text { https://shopee.co.id/Pandu-coffee-i.178637812.7752867201 } \\
\text { - Tokko.io: https://tokko.io/panducoffee } 0\end{array}$ \\
\hline
\end{tabular}

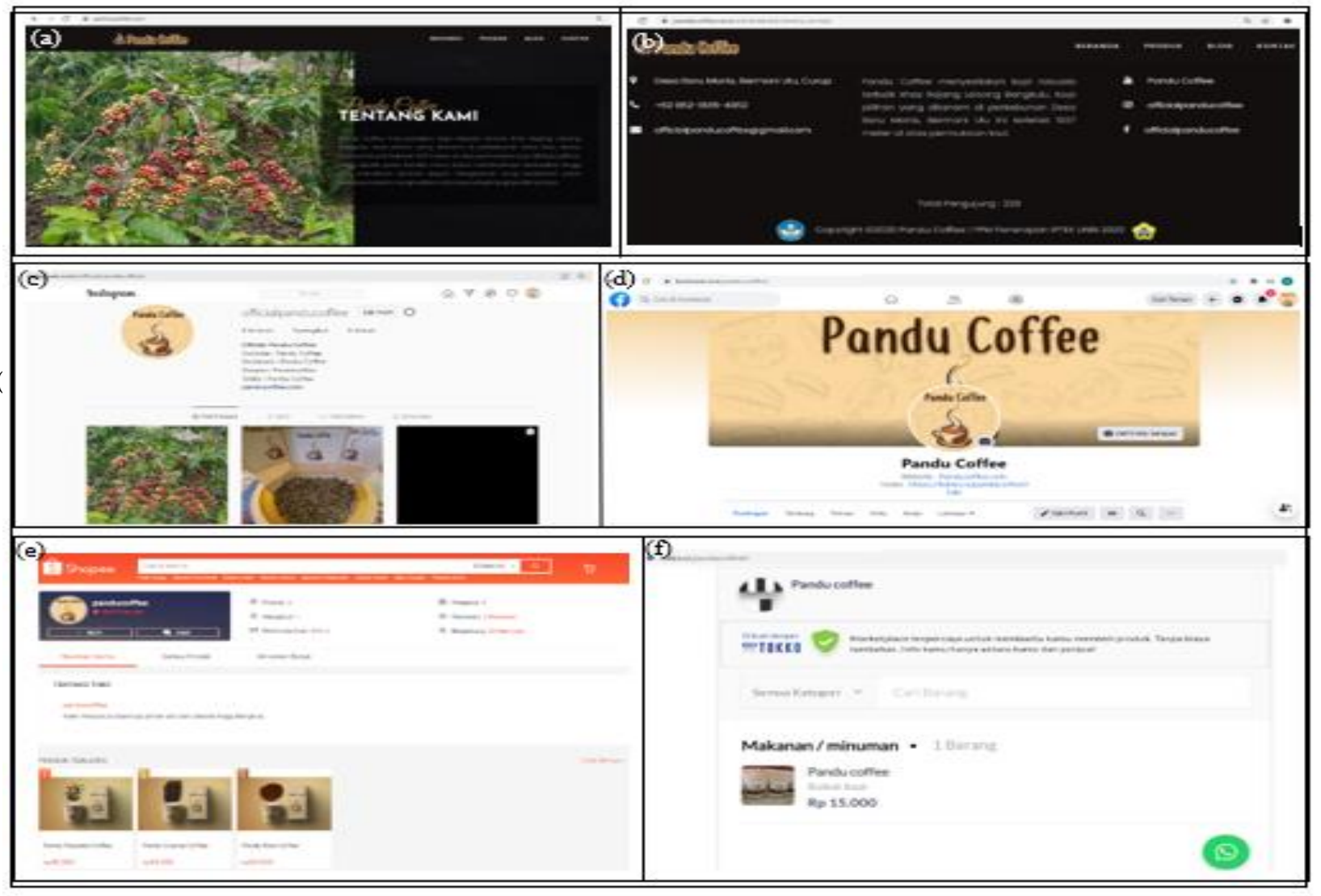

Gambar 6. Hasil Screenshot e-commerce produk Pandu Coffee. (a dan b) halaman website, (c) instagram, (d) facebook, (e) halaman shopee dan (f) halaman tokko.io. 
Website Pandu coffee pertama kali diresmikan pada 30 September 2020 bersama semua anggota kelompok Tani Pangestu Rakyat. Jumlah pengunjung website terus dipantau untuk melihat sejauh mana keberhasilan proses pemasaran online dilakukan. Sebagai salah indikator keberhasilan proses pemasaran, tim pengabdian memasang tools untuk menghitung jumlah pengunjung website secara otomatis. Akumulasi jumlah pengunjung dicatat setiap 10 hari dan grafik penambahan jumlah pengunjung website Pandu Coffee ditunjukkan pada Gambar 7. Hingga 20 November 2020, jumlah pengunjung mencapai 228 orang. Penambahan signifikan terjadi pada tanggal 10 Oktober hingga 20 Oktober, yaitu mencapai 75 orang. Penambahan ini terjadi karena bersamaan dengan pengisian histori pada halaman facebook dan instagram yang merupakan media lain dalam melakukan pemasaran. Kedua media sosial ini cukup signifikan berperan dalam menambah jumlah pengunjung website. Meskipun demikian, belum ada penambahan jumlah pembeli melalui marketplace shopee dan tokko.io. Pembeli umumnya berkomunikasi langsung dengan penjual melalui aplikasi Whatsapp yang kontaknya didapatkan oleh pembeli pada halaman website.

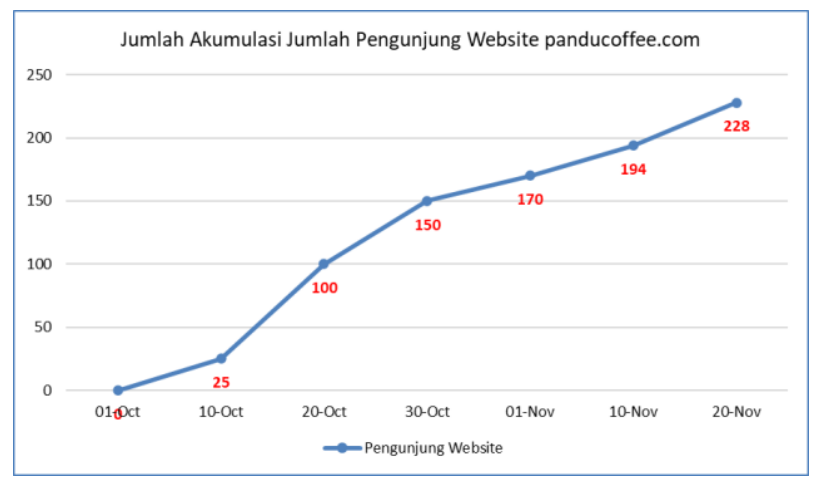

Gambar 7. Grafik akumulasi jumlah pengunjung website hingga 20 November 2020

Penambahan jumlah penunjung website diikuti dengan penambahan omset hasil penjualan produk pandu coffee. Semula mitra hanya berhasil menjual $55 \mathrm{Kg}$ atau setara 220 kemasan bubuk kopi selama 11 bulan dengan keuntungan Rp. 2.242.000,-. Berdasarkan catatan penjualan produk mitra, sejak melakukan promosi melalui media sosial dan website, dalam waktu 2 bulan (Oktober-November 2020) mitra berhasil menjual produk Pandu Coffee sebanyak $125 \mathrm{~kg}$ atau setara dengan 500 kemasan. Nilai penjualan produk selama 2 bulan ini mencapai Rp. 7.500.000,- dengan modal produksi Rp. 2.500.000,- dan memperoleh keuntungan sebesar Rp. 5.000.000. Meskipun belum ada pembelian melalui marketplace online, umumnya pembelian melalui via chat Whatsapp. Delapan puluh lima persen $(85 \%)$ Pembeli kebanyakan datang dari luar Desa Barumanis yang memesan produk kopi dalam jumlah cukup banyak dan $15 \%$ pembeli lainnya berasal dari desa setempat yang membeli bubuk kopi untuk keperluan acara pernikahan anggota keluarganya. Penerapan pemasaran online dinilai cukup efektif bagi usaha mikro milik kelompok Tani Pangestu Rakyat. Dimana hal tersebut dapat dilihat dari perubahan sebelum dan setelah menerapkan pemasaran online dalam penjualan produk khususnya dalam jumlah pendapatan. Perbaikan dalam hal pengemasan, pemasaran dan penjualan online terus dilakukan oleh mitra dan didampingi oleh tim pengabdian kepada masyarakat LPPM Universitas Bengkulu.

\section{KESIMPULAN}

E-Commerce untuk Optimalisasi Pemasaran Produk di Era Digital Bagi Usaha Mikro Kelompok Tani Pangestu Rakyat Desa Barumanis Kecamatan Bermani Ulu Kabupaten Rejang Lebong“ telah selesai dilakukan. Beberapa indikator capaian program pengabdian telah diperoleh, mulai dari pembuatan dan penggunaan kemasan produk, pembuatan akun media sosial dan interface e-commerce seperti Facebook, Instagram, Youtube dan website. Proses pemasaran produk berjalan cukup baik yang ditunjukkan dengan adanya penambahan jumlah pengunjung website setelah 2 bulan diresmikan. Pemasaran terus dilakukan dengan memanfatkan mediamedia sosial dan halaman website.

\section{UCAPAN TERIMA KASIH}

Program pengabdian kepada masyarakat ini didukung dan danai dari DIPA Universits Bengkulu Nomor: SP DIPA-023.017.2.677529/2020 tanggal 27 Desember 2019 melalui PPM berbasis IPTEKS tahun anggaran 2020 dengan No Kontrak: 2367/UN30.15/AM/2020.

\section{DAFTAR PUSTAKA}

Disa, S. (2011). E-Commerce Sebagai Solusi Pemasaran Bagi Usaha Mikro Kecil Dan Menengah (UMKM). Inspiration: Jurnal Teknologi Informasi dan Komunikasi, 1(2), 1-13.

Hadiwijaya. H, Febrianty, Darmawi. (2019). Pendampingan Komunitas UMKM Batu Bata melalui Penggunaan Aplikasi Perhitungan Stock berbasis Ecommerce di Desa Pasir Putih Ujung Kecamatan Talang Kelapa Kabupaten Banyuasin. ENGAGEMENT: Jurnal Pengabdian Kepada Masyarakat, 3(2), 262-270.

Harminingtyas, R. (2013). Analisis Fungsi Kemasan Produk Melalui Model View dan Pengaruhnya Terhadap Keputusan Pembelian Konsumen Pada Produk Rokok Kretek Merek Dji Sam Soe Di Kota Semarang. Jurnal STIE Semarang, 5(2). 
Irmawati, D. (2011). Pemanfaatan E-Commerce dalam Dunia Bisnis. Jurnal Ilmiah Orasi Bisnis, Edisi KeVI, 95-112.

Maulana, S. M, Susilo H, Riyadi. (2015). Implementasi E-Commerce Sebagai Media Penjualan Online (Studi Kasus Pada Toko Pastbrik Kota Malang). Jurnal Administrasi Bisnis (JAB), 29(1), 1-9.

Mumtahana, H. A, Nita. S, dan Tito. A. W. (2017) Pemanfaatan Web E-Commerce untuk Meningkatkan Strategi Pemasaran. Khazanah Informatika: Jurnal Ilmu Komputer dan Informatika, 3(7): 6-15.

Nasrullah. D, Hidayatullah. A, dan WP. Satria, U. (2017). Pendampingan E-Commerce dan Pendidikan di Cerme Kecamatan Ngimbang Lamongan. Aksiologiya: Jurnal Pengabdian Kepada Masyarakat 1(1), $11-17$.

Pitriyani dan Kasmi. (2019). Pengembangan Aplikasi ECommerce Sebagai Media Pemasaran Produk Umkm Di Kabupaten Pringsewu. Prosidding Konferensi Mahasiswa Sistem Informasi. 5(1), 425-433.

Rahman., A. N dan Ramdani, C. M. S. (2016). IbM Pelatihan Pemanfaatan E-Commerce Sebagai Media Pemasaran Global Untuk Peningkatan Penjualan Produk Kelom Geulis (Studi Kasus: UKM kelom geulis Tamansari Tasikmalaya). Jurnal Siliwangi: Seri Pengabdian Pada Masyarakat, 2(1), 64-68.

Sugiyanto, Karima. A, Yoganati, A. F. (2017). Peningkatan Ketrampilan Pembuatan Desain Kemasan serta Pemanfaatan Media Promosi dan Pemasaran Online Pada Kube Ash-Shidiqqy dan Pik Abdussalam Jepara. Techno.COM, 16(1), 9-16.

Sutanto, F. A, Supriyanto. A, Purwatiningtyas. (2015). Penerapan E-Commerce Berbasis CMS dan SEO untuk Toko On-Line UMKM. Jurnal Abdimas, 19(2), 91-100.

Utami, S. S dan Aini, S. (2019). Pemanfaatan ECommerce dalam Upaya Meningkatkan Penjualan Produk Handycraft Mama Art Deco. Intervensi Komunitas: Jurnal Pengabdian Masyarakat, 1(1), 2133.

Wibawa, M. B, dan Fahrizal. (2019). Pelatihan ECommerce Bagi UMKM Aceh E-Commerce Training for Aceh SMES. Jurnal Pengabdian Masyarakat INOTEC UUI, 1(2), 6-9

Yulistia. (2017). Analisis Pengaruh Efektivitas Dan Manfaat E-Commerce Terhadap Sikap dan Perilaku Pengguna dengan Menggunakan Metode TAM (Studi Kasus: UKM Kota Palembang). Jatisi, 4(1), 93-100.

Zen, Z. H, Satriardi, Dermawan, D, Anggraini. D. A, (2017). Pelatihan Desain Kemasan Produk Umkm di Kecamatan Tambang, Kabupaten Kampar. Jurnal Pengabdian untuk Mu Negeri, 1(2), 12-15. 